\title{
Contemplating the Future of Clinical Legal Education
}

\author{
Jeff Giddings ${ }^{*}$
}

This article considers the factors that are likely to continue to shape the future of clinical legal education. Drawing on the history of clinical legal education, both in Australia and more broadly, the article considers how those involved in clinical programs might best promote program sustainability. The article examines the continuing creative tension between goals related to student learning and those related to community service, as well as considering the emergence of new forms of clinical lawyering. It recognises the importance of utilising clinical insights across the broader law program, and advocates for an emphasis on the natural strengths of clinic-based learning in terms of students developing effective frameworks for addressing ethical issues and developing strong links with the practising profession. The article also calls for close attention to be paid to developing effective practices in student supervision. Such endeavours can be advanced through developing the awareness of supervisors regarding the range of matters that can impact on their work with students, including a better understanding of the supervision practices used in other disciplines. The article also addresses the prospect of an increasing focus on graduate clinical programs designed to prepare law graduates for their entry to the legal profession.

This article serves as a reference point for the Griffith Law Review symposium on clinical legal education. It provides an overview of issues that will continue to shape the development of clinical legal education. It is principally Australian in focus, while also drawing on relevant history and developments elsewhere. In order to move forward, those of us interested in clinical legal education need to reflect on our heritage and plan for the future, in particular identifying how clinical programs can be made sustainable for the long term. Despite its importance in maximising the benefits of clinical legal education, little has been written about what systems and practices might best foster program sustainability.

Recent publications from the United States, ${ }^{1}$ Scotland $^{2}$ and Australia ${ }^{3}$ have reinvigorated debates regarding legal education. In the United States in particular, clinical legal education has been identified as having considerable

Griffith Law School. Thanks to Helen Kinniburgh, the two referees and my colleague Kieran Tranter for their comments on an earlier version of this article.

Sullivan et al (2007); Stuckey et al (2007).

Maharg (2007).

Johnstone and Vignaendra (2003). 
scope for enlivening and enhancing the education of future generations of lawyers. The Educating Lawyers report, published in 2007 by the Carnegie Foundation for the Advancement of Teaching, emphasises the particular contributions clinical experiences should make to the practical and professional apprenticeships that are integral parts of an effective legal education. ${ }^{4}$ The Best Practices for Legal Education report, published in 2007 by the Clinical Legal Education Association, provides a compelling analysis of the multiple failings of legal education in the United States, and emphasises the multiple roles that should be played by experiential legal education. ${ }^{5}$

The key challenge to greater use of clinical teaching remains its resourceintensive nature. Multiple strategies can be applied in seeking to effectively meet the resourcing challenge (in terms of fortifying existing support as well as accessing new forms), along with making the best use of those resources, providing valuable learning experiences to as many students as possible. This will require the development of new partnerships both within and beyond law schools, as well as the enhancement of our collective understanding of different clinical methodologies, from simulations and externship arrangements to various forms of real client experiences. Important issues of how to effectively integrate and sequence various forms of clinical experience warrant closer scrutiny if the benefits of such experiences are to be shared effectively and broadly.

\section{Clinical Legal Education Across the Globe}

Countries including Australia, ${ }^{6}$ Canada, ${ }^{7}$ Chile, ${ }^{8}$ England, ${ }^{9}$ India,,${ }^{10}$ South Africa,,${ }^{11}$ the United States ${ }^{12}$ and Zimbabwe ${ }^{13}$ saw the development of clinical programs in the 1960s and 1970s. ${ }^{14}$ New law schools with young academics and socially active students were responsible for much of this development. ${ }^{15}$ Chile, India, South Africa and Zimbabwe are examples of nations where community service imperatives and state expectations about law schools playing a substantial role in legal service delivery were central to the establishment of the early clinics. ${ }^{16}$

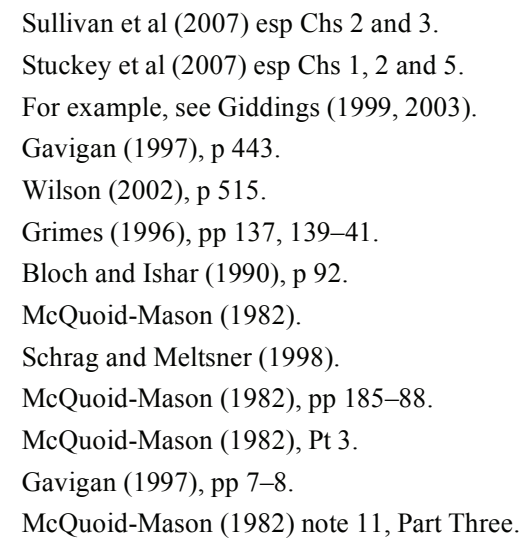


Clinics developed in other nations across Eastern Europe, Latin America, Asia, Africa and the South Pacific through the late 1990s and into the twentyfirst century. While the 1970 s were described as the decade of the clinics in the United States, ${ }^{17}$ it has been the past 10 years that have seen greater development of clinical legal education across the globe. Many of the clinical programs established in developing countries have been supported with resources from charitable and other foundations based in the United States, including the Ford Foundation, the Open Society Justice Institute, the Central European and Eurasian Law Initiative (CEELI) of the American Bar Association and the Public Interest Law Initiative (PILI) of Columbia Law School. These externally sponsored programs raise particular sustainability issues. Charitable funding tends to be available principally for program development and establishment, with an expectation that local sources will need to provide ongoing resources. There are also critical cultural issues and resource implications related to the application of US models of clinical legal education in other jurisdictions. ${ }^{18}$

In Australia, there has been growing interest in clinical legal education. The year 2003 saw the commencement of a new clinical program at Deakin University, ${ }^{19}$ while 2004 marked the development of programs at the Australian National University, ${ }^{20}$ Bond University, ${ }^{21}$ Macquarie University, ${ }^{22}$ the University of Queensland ${ }^{23}$ and the University of Sydney. ${ }^{24}$ Several trends are evident in these developments. Law schools are no longer developing clinical programs through establishing their own clinic site. Rather, clinics are being grafted on to existing community and government agencies. It is now more than a decade since La Trobe developed a clinical partnership with Victoria Legal Aid, the first Australian clinic not involving a community legal centre. ${ }^{25}$ There has also been a proliferation of 'public interest' clinical courses with such courses now available at seven law schools. ${ }^{26}$

17 Condlin (1983), p 604.

18 See, for example, Dowdle (2000-01), p S56.

19 National Pro Bono Resource Centre (NPBRC) (2004), p 18. Deakin operates clinics with Geelong Community Legal Service and Western Suburbs Community Legal Service, and identifies community service as a major program aim.

20 NPBRC (2004), p 16. An advice service for young people, run with Legal Aid ACT, Clayton Utz (a local law firm) and youth advocacy groups.

21 NPBRC (2004), p 17. An administrative law clinic operated with the Queensland Public Interest Law Clearing House (QPILCH). See QPILCH (2004).

22 NPBRC (2004), p 22. Macquarie operates clinics with Macquarie Legal Centre and the Public Interest Advocacy Centre.

23 NPBRC (2004), p 31. A consumer credit clinic run with Clayton Utz (a local law firm) and the Queensland Public Interest Law Clearing House.

24 NPBRC (2004), pp 31-32. Sydney operates external placement programs and is developing an 'Amicus Litigation Clinic'.

25 Dickson and Noone (1996), p 845.

26 Griffith University, La Trobe University, Macquarie University, Monash University, University of Newcastle, University of Sydney and the University of Western Sydney. See NPBRC (2004). 
This broader use of clinical pedagogy in Australian law schools has the potential to foster further development. Nonetheless, it has been suggested that 'before clinical legal education will gain a stronger foothold in Australian legal education, existing programs will need to be rigorously evaluated to demonstrate the nature and extent of improvements to student learning deriving from these programs'. ${ }^{27}$

Specialist clinical programs have become increasingly prominent in the 12 years since Monash developed Australia's first such program. ${ }^{28}$ There are now seven clinic options at Griffith Law School, five of a specialist nature. The University of New South Wales (UNSW) Law School provides six clinical experiences, with most being based at Kingsford Legal Centre. There are five clinic options at Newcastle, four at La Trobe and four at Monash. ${ }^{29}$

This growing interest in clinical teaching in law may overstate the state of health of the Australian clinical movement. There is still a lack of what might be described as 'clinical fluency' amongst Australian law schools. The practicerelated experiences of clinical academics tend not to be effectively utilised across the teaching and research endeavours of law schools. The sustainability of any clinical program will depend on how effectively its advocates can anticipate and address concerns, as well as identify opportunities and emphasise natural strengths. The demands on clinical programs are so diverse and complex that it will not be possible to satisfy them all, prompting the need to focus on those dimensions of law teaching and legal research best suited to the use of clinical methods and insights.

\section{Promoting the Sustainability of Clinical Programs}

The Australian clinical movement would benefit from examining how to foster the sustainability of clinical programs. Sustainability relates to the ability of something to be sustained or upheld. ${ }^{30}$ Sustainability recognises the importance of ongoing development, whereas the notion of maintenance refers more to the continuation of something that currently exists. Sustainability has become an increasingly significant concept in relation to the environment, resource development and the conduct of corporations. ${ }^{31}$ It is now described as a 'cornerstone of public sector management', having the potential to improve the actual performance of government organisations..$^{32}$

As relatively small entities, clinical programs are susceptible to rapid change on a range of fronts. Such change may relate to staffing, resourcing, university and law school policy developments or partnerships and cooperative

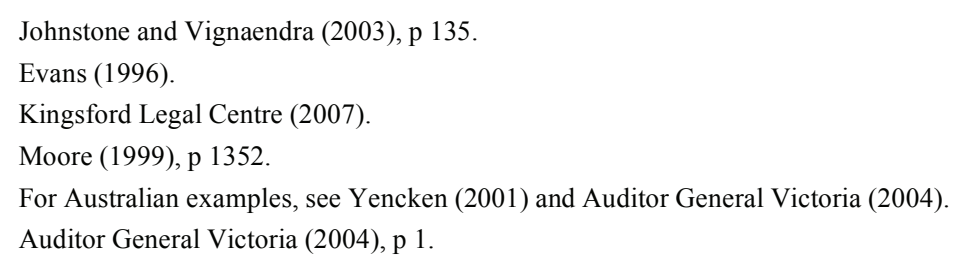


arrangements. The fate of clinical programs is also linked to the future directions of universities and the legal profession. ${ }^{33}$

Resourcing issues are often foremost in the thinking of those considering the use of clinical teaching methods. The service expectations that will inevitably be linked to external funding need to be balanced with maintaining the focus on student learning. Providing an intense and productive clinical experience for students needs to be balanced with making such experiences available to as many students as possible. This, in turn, needs to be considered in light of the supervision loads and other teaching, research and professional responsibilities faced by clinical academics.

A key difficulty for law teaching in Australia, and therefore a factor limiting the further development of clinical legal education, is the Relative Funding Model used by the federal government since 1991 to allocate teachingrelated operating grants to universities. Law was placed in the bottom five discipline clusters, along with economics, accounting and various humanities with a weighting of 1 . By contrast, the top cluster (comprising medicine, dentistry and veterinary science) has a weighting of $2.7 .^{34}$ This all means that, while HECS payments by law students are at the highest level, government funding is at the lowest level. ${ }^{35}$ Cheap ways of teaching remain the default position for Australian law schools, and this influences the ways in which supporters of clinical teaching can best advocate to sustain existing programs and promote the development of new programs.

One way in which thinking on sustainability can be applied to clinics may be in enabling us to understand the resistance of law school colleagues and the legal profession to the introduction of clinic teaching. Dunphy and colleagues refer to a sustainability phase model which is focused on attitudes to change, especially initial resistance followed by acceptance. ${ }^{36}$ The later stages of the phase model (efficiency, strategic proactivity and the sustaining corporation) are those most important to the ongoing development of clinics.

Barnhizer refers to there having been four phases in the development of clinical legal education and methodology in the United States. ${ }^{37}$ During the 1960 s, clinical education initially formed part of 'an often inchoate assertion of the need for reform of legal education'. Clinic formed part of a 'collision of what was perceived to be radically different values concerning the proper role of legal education'. ${ }^{38}$ There was then an experimental phase, with advocates aggressively asserting that their theory about the special learning effects of clinical methodology was 'indisputable fact'. This theory was then tested

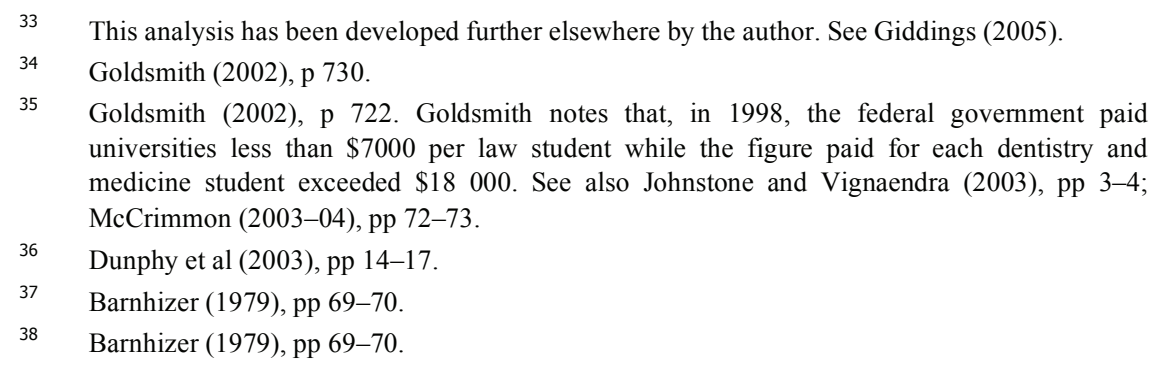


through the development of a variety of programs with assistance from the Council on Legal Education for Professional Responsibility. ${ }^{39}$ The third phase saw consolidation, reflection and refinement of the experimental findings, leading to an intensification of the 'overall understanding of theory, process and subject matter'..$^{40}$ The fourth phase involved clarification and assertion of the proper role of clinical education in relation to the total curriculum, but 'with specific data, concepts and knowledge about how best to achieve legitimate ends'. ${ }^{41}$

Barnhizer's analysis could be applied to the sustainability of individual clinical programs and is also helpful in the Australian context. Establishment of clinical programs will be facilitated by recognition of the need for reform of legal education and a preparedness to look to new methodologies. Sustainability will require early experimentation, with both existing and new versions of clinical method, followed by review and consolidation. Then, in order to maintain a significant position in legal education, clinical methodology and individual clinical programs will need to have arguments and evidence to address criticisms as well as the flexibility to respond to changing circumstances.

In her analysis of the nature of community development, Kenny has identified a range of key features that may be relevant to clinical programs. Effective community development generally involves a commitment to subsidiarity - the idea that 'power should be devolved to the lowest level possible, consistent with the effective governance of the affairs in question' ${ }^{42}$ It also involves the establishment of supportive communities, based on developing and sharing resources and social interaction and participation. Outreach methods can be used to enable increased participation and overcome isolation. ${ }^{43}$ These features suggest the importance of a collegial approach within law schools.

Dunphy and colleagues refer to the practices designed to enhance sustainability as being linked to the capacity to innovate and escape from rigid models of operation and production. Reference is made to characteristics including communicating results readily, facing an accelerating rate of change and an increasingly complex society. Innovation depends on cultural and structural characteristics of the organisation. ${ }^{44}$ This analysis focuses on large organisations, and identifies the need for organisations to be structured so as to facilitate planning and foster flexibility and creativity. Developing structures to achieve these apparently conflicting aims appears to be particularly difficult for large organisations. Clinical programs need to recognise the complex nature of the environments in which they operate, as part of large and often complex universities.

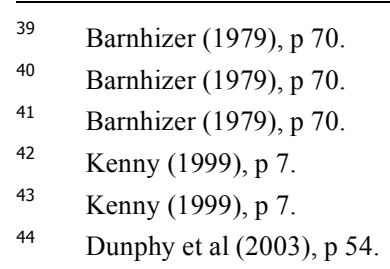


Dunphy and colleagues identify the importance of clear strategy for organisations which operate in a turbulent world, an environment that is much more political, chaotic and disorganised than rational decision-making models imply. ${ }^{45}$ Strategy must be articulated clearly and embodied in specific action plans for every unit and individual. Important capabilities and competencies include strategic flexibility in adapting to fast-paced environmental change, strategic leadership, dynamic core competencies, developing human capital, effective use of new technology, and engaging in valuable strategies including development of strategic alliances and cooperative strategies. ${ }^{46}$

This analysis of what fosters sustainability suggests that clinical programs will benefit from articulating clear program objectives and then going through the challenging process of prioritising those objectives and adopting a flexible approach to implementing the prioritised objectives. Such a process will provide a platform for developing the strategies needed to pursue those objectives.

\section{Learning and Service: The Perpetual Tension}

Perhaps the most contentious aspect of clinical legal education involves the potential for tensions between objectives related to student learning, community service and the legal professional responsibilities of supervisors. ${ }^{47}$ These tensions are simply too important to be ignored. In many respects, they can be managed creatively but there will be aspects of these objectives that cannot be reconciled. Clinic teachers need to identify such aspects and then prioritise, structuring their programs to address those priorities.

Clinical supervision involves an unusual form of legal practice, where partial responsibility for client work is delegated to the student for the purpose of student learning. In most legal practices, supervisors delegate work to less senior lawyers and paralegals because of pressure of business and to maximise fee-generation..$^{48}$ Tensions also arise between the interests of clients and those of students. The legal work required by a client can almost always be done more quickly and effectively by an experienced lawyer than by a student.

Such concerns are long-standing. In 1972, Allen Redlich wrote of his experiences in 1969-70 running a 'relatively large service-oriented clinical program' at the University of Wisconsin. ${ }^{49}$ Redlich illustrated the tensions highlighted above, suggesting that many problems appeared unique to that type of placement..$^{50}$ His most serious criticisms related to the variable nature of student supervision provided by the lawyers working in the host legal aid office,

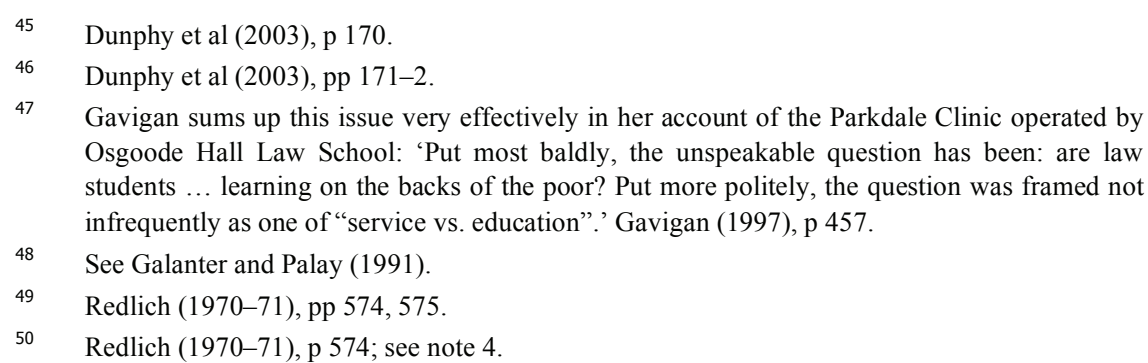


which led to 'many unsatisfactory experiences'. The staff attorneys, 'although vigorous and motivated, had no experience and, being unable to supervise, avoided their responsibilities, leaving it to the student to seek supervision'. ${ }^{51}$ While some students did excellent work with effective supervision, others 'came and went as they wished and abandoned files were common'. ${ }^{52} \mathrm{He}$ further stated that, while some students 'enjoyed the freedom to make decisions, give advice, and, to a high degree, practice law independently, others recognized that the clients and occasionally they, too, were being imposed upon'. ${ }^{33}$ These are serious criticisms from both service and educational perspectives.

Kevin Bell, the solicitor responsible for the La Trobe clinical program from 1981 to 1985 and now a Justice of the Victorian Supreme Court, was driven by client service concerns in the operation of that clinic. 'The educational needs of the students did not figure highly in decisions made about whether a case was picked up or not. The focus was on the needs of the client, what we could do for them with the limited resources we had and whether or not a particular case was worthy of our follow-up or personal attention because it had consequences beyond the immediate. ${ }^{54}$ Bell also noted the complexity for a clinic in balancing 'three competing policy priorities' — casework, community action and legal education.

The 1987 Report of the Discipline Assessment of Australian Law Schools expressed doubts about the efficacy of seeking to combine legal education and legal aid 'in view of the extremely heavy demands on the office and its very large practice'. ${ }^{5}$ In relation to Springvale Legal Service, the key site of the Monash clinical program, the report stated:

Its primary goal really is the provision of legal services to the community. We heard criticisms of this in terms of the time and supervision which can be devoted to the education of students. Such a relationship is often not entirely satisfactory. ${ }^{56}$

While the phrase 'not entirely satisfactory' could easily have been applied to almost all dimensions of Australian legal education in the $1980 \mathrm{~s}$, it is notable that the Monash clinical program subsequently modified the 'drop-in' nature of its clinic sessions, placing a limit of 15 clients per session in the interests of rationalising supervisor and student workloads. ${ }^{57}$

Simon Rice discusses this enduring tension in terms of the approach taken to student supervision. "The simple conflict is one between an experiential approach to learning, in which the teacher encourages a reflective and

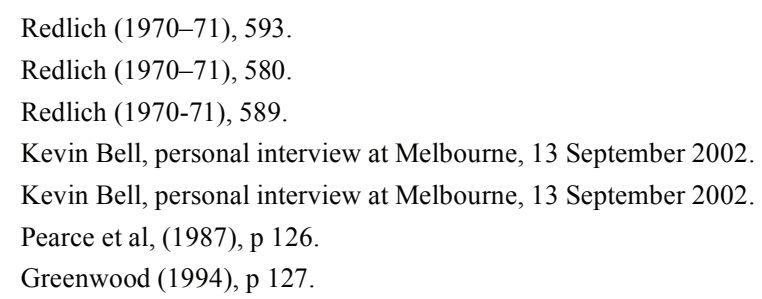


responsible approach to the students, and a directive approach to case management." 58 While Boon asserts that 'In conflicts between student's educational needs and clients needs, the former must triumph',59 Grimes highlights that one of the hardest aspects of clinical work with real clients is 'turning away a client in need'. ${ }^{60}$ Turning away cases is particularly difficult for many students, as they tend to have limited experience of prioritising different claims on scarce resources, and often are the ones expected to explain unwelcome decisions to clients.

Australian clinics continue to view community service as an important element of their programs. These clinics have been shaped to a significant extent by the backgrounds of the people working in them. Australian clinical programs tend to have been, and continue to be, staffed by people with a strong community legal centre or legal aid background, bringing with them a strong commitment both to delivering casework services to people who would otherwise be unable to access legal processes and to using the law and legal system to achieve community development objectives. ${ }^{61}$ In several interviews conducted by the author, many clinicians involved in early Australian programs have explained that they started their time as student supervisors without having considered the teaching side of the process in great detail. They tended to be more concerned with community service and law reform issues.

The federal government has contributed to the community service focus of Australian clinics through its financial support of clinical courses at Griffith, Monash, Murdoch and the University of New South Wales. After funds were provided for a three-year pilot clinical partnership with Murdoch University in 1996, support was extended to cover four clinical programs in 1999 and has continued since. ${ }^{62}$ Daryl Williams, the Attorney-General responsible for providing funds to clinical programs, considered the main purpose of clinical legal education to be community service, describing the added educational outcomes as 'the icing on the cake'. ${ }^{63}$ Williams referred particularly to the similarities between clinical programs and community legal centres, and the ability of clinics to deliver inexpensive legal services to low-income members of the community.

Australian clinical programs appear to have become more effective in pursuing the potentially conflicting objectives of learning and service. They have developed their use of a broader range of clinical models and fostered multi-disciplinary approaches. They have also increasingly emphasised the importance of clinical experiences in developing the ethical awareness and community service commitment of law students.

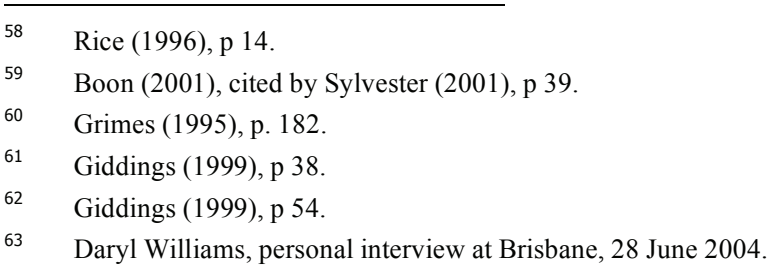


Australian clinic teachers have also developed their understanding of student learning issues over the past decade. There is now greater acceptance of the value of clinics that do not provide ongoing casework services. Even with clinics that include a focus on referring clients to other appropriate services, concerns have been expressed that for 'clinical programs [which] receive their cases from courts, legal aid offices, pubic defenders' offices, or other indirect sources, it may not always be possible to get cases at the optimal time for students'. ${ }^{64}$ Discussions with clinic teachers, past and present, reveal a developing understanding of the scope for improving service and law reform achievements through more effective teaching practices. ${ }^{65}$ There is also a greater awareness of the potential for clinic-based learning to be linked with and complement the other learning in which law students are involved. Promoting the integration of clinical insights across the broad sweep of law studies has the potential to enhance law teaching as well as promoting the sustainability of clinical programs.

\section{Forms of Clinical Lawyering}

Australian clinical programs are now increasingly focused on taking their work beyond the traditional service delivery model of advice and representation for individual clients. This is being done principally to enrich student learning and also to enhance the community service impact of the work of clinic students and teachers.

Clinical programs in New South Wales have a particularly impressive record of running major superior court public interest cases. The clinical program at the University of Newcastle has undertaken important litigation on issues regarding police accountability ${ }^{66}$ in tandem with other mechanisms, including strategic work with the media, submissions to government and acting at coronial and other inquiries. The University of New South Wales clinical program ran a series of High Court anti-discrimination matters in the $1980 \mathrm{~s},{ }^{67}$ and more recently was involved in litigation seeking compensation for members of the Stolen Generations. ${ }^{68}$ In an interview, Neil Rees, the Kingsford Legal Centre Director from 1981 to 1986 , who ran the anti-discrimination cases, questioned the extent of student learning from involvement in such cases: 'I don't think they were particularly great learning experiences for the students simply because the issues were too sophisticated ... I can't think of one student who really wrapped their head around the issues. They didn't have the time.

\footnotetext{
$64 \quad$ Dinerstein (1991), p 566.

65 These insights come from a 'roundtable' discussion conducted on November 20, 1996 at Clayton with Sue Campbell, Adrian Evans, Ross Hyams, Guy Powles, Neil Rees and Simon Smith.

66 See Eastman v The Queen [2000] HCA 29 (25 May 2000); Watterson et al (2002).

67 Giddings (1992), p 263; Giddings (2003), p 14.

68 Williams $v$ The Minister Aboriginal Land Rights Act 1983 and The State of New South Wales [2000] NSWCA 255.
} 
They didn't have the experience. I mean, I can remember the most gifted students being involved in these cases. ${ }^{69}$

Other clinics have adopted community development models with a view to involving their clients and others in addressing issues of community concern. Such models utilise non-casework approaches and yet are obviously informed by the casework conducted by the clinical program and linked community agencies. Examples of such approaches are those developed at Monash and Griffith Universities. Adrian Evans refers to the process of community development identified in the 1970 s by the Brazilian educator Paulo Friere and the need for clinicians to help students and clients to move beyond individual reflection to group reflection upon the underlying social injustices which diminish an equitable society'.$^{70}$ At La Trobe, Liz Curran has emphasised the importance of involving clinic students in law reform work, as this exposes them 'to the broader role they may wish to play in public life when they are fully fledged lawyers encouraging their participation in their law association and to be unafraid in speaking out against injustice'. ${ }^{71}$

The Griffith clinical program has involved students working in groups on community development projects. Given the complex and ongoing nature of many community concerns, discrete projects are designed in relation to particular issues which can be completed by successive groups of students, each building on the work done by previous groups with continuity being provided by clinic and community legal centre staff acting as project supervisors. Project areas have included property rights of mobile home park residents and litigation funding arrangements (particularly 'no win, no fee').

Australian law schools and universities now appear to expect more and more from their clinical programs and clinicians. Clinics are promoted to students as the best environment in which to develop 'hands on' legal skills while being showcased to the general community as examples of university commitment to community service and access to justice. Interestingly, there have been name changes for several Australian clinics, changes clearly designed to more closely connect these clinics with their law school and university. Springvale Legal Service has become the Springvale Monash Legal Service and the Newcastle Legal Centre has become the University of Newcastle Legal Centre. $^{72}$

If unrealistic expectations are placed on clinics by universities and law schools, this will inevitably result in the compromising of some program aims. The strength of community service expectations is likely to continue to limit the focus on student learning. To satisfactorily address the underlying tensions, clinical programs will need to prioritise the various program aims. Further, where clinic aims have been prioritised, these need to be supported and resourced by the law school and university.

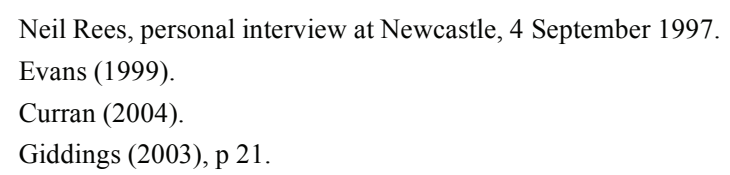




\section{Emphasising Ethics, Values and the Public Interest}

Closely linked to the tension between community service and student learning is the issue of the emphasis to be placed by clinical programs on ethics, values and public-interest issues. Statements have regularly been made as to the capacity of clinical programs to enhance the commitment of students to professional ideals and values. ${ }^{73}$ Evans refers to "the dream of every clinical teacher to prove that a "clinical experience" in law school will re-order the priorities of law students in favour of public interest lawyering' ${ }^{74}$

While limited empirical evidence exists to support assertions regarding clinical experiences promoting a public interest commitment, it is clearer that participation in a clinical program makes it more likely that students will deliver pro bono services through volunteering at a community legal centre. The Keys Young 1990 survey of students who had completed the clinical program at the University of New South Wales saw 60 per cent of respondents agree that 'their clinical experience influenced them to take or maintain an interest in community legal centres'. ${ }^{75}$ This volunteer ethic continues to reinforce the strong community service focus of clinical programs such as those at Monash and the University of New South Wales, which benefit from substantial volunteer input, particularly from practitioners who participated in the clinic during their law studies.

The ethics focus of Australian clinical legal education has been more clearly articulated in recent years. Styles and Zariski have referred to the increasing importance of legal education goals related to development of professional ethics and student-centred learning along with development of student understanding of the relationship between theory and practice and the development of technical skills. ${ }^{76}$ They consider clinics well placed to counter some of the negative influences of traditional legal education on students' commitment to the public interest. ${ }^{77}$ The Best Practices Report has similarly called for US law schools to expand their use of experiential education as 'a powerful tool for forming professional habits and understandings' ${ }^{78}$

Judith Dickson and Mary Anne Noone rightly identify that the clinical setting 'constantly gives rise to spontaneous and various ethical questions which challenge and test students'. ${ }^{79}$ Given that written ethical conduct rules are 'signposts at the crossroads not a fence along the entire length of the highway', ${ }^{80}$ clinics provide students with opportunities to develop the ability to identify and address ethical issues in relation to matters including conflict of interest, confidentiality and legal professional privilege.

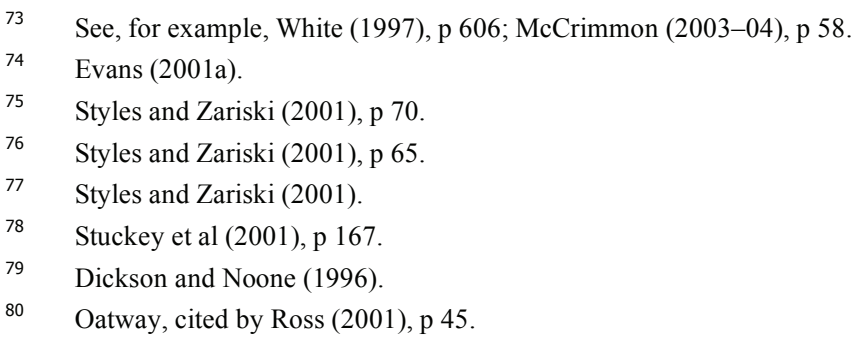


Since 1994, La Trobe Law School has included a clinical component in the ethics subject required for admission to legal practice. This was a significant development in several respects. The clinic placement is combined with a seminar series which harnesses the opportunity for students to 'reflect on the way a practitioner's duties and ethics are relevant to daily legal practice as well as on the efficacy of law, the legal system, the legal aid system, the legal profession and the nature of justice' ${ }^{81}$ This was also the first Australian clinical program to involve students taking responsibility for clients within the practice of a major statutory legal aid office rather than a community legal centre.

The Murdoch Law School clinical program (known as SCALES - the Southern Communities Advocacy Law Education Service) emphasises the importance of involving students in providing legal assistance to asylum seekers. In 2000, Mary Anne Kenny and Anna Copeland persuasively argued that such cases are effective in 'encouraging students to recognise systemic injustice'. ${ }^{82}$ These cases 'have a profound effect on the students as they are faced with the broader social and political issues that these cases present'. ${ }^{83}$ The intensification of the Australian public debate on asylum seeker issues in the early years of the twenty-first century reinforces their argument. Kenny and Copeland state that what they 'hope to achieve as clinical supervisors is to foster a "rights based" methodology that students will apply across all their legal work. This involves students gaining an understanding of, and a commitment to, fundamental human rights as an important principle of any legal practice. ${ }^{84}$

At Monash, Adrian Evans continues to engage in work seeking to more clearly articulate the links between community development processes and the development of values in law students. Evans has written of the need for clinical supervisors to stimulate respectful argument amongst their students in relation to competing moral viewpoints identified through the process of community development. ${ }^{85} \mathrm{He}$ has also been involved in major projects designed to determine the values which appear to characterise the mass of Australian lawyers in their early careers. ${ }^{86}$ Such work demonstrates the potential for linking the teaching and research dimensions of clinic-based work.

It is clear that clinics are naturally well placed to promote student learning related to ethics and values. Advocates for clinical programs can emphasise this natural advantage in terms of students encountering the ethical dimensions of practice through clinic-based work with clients, as well as seeing such ethicsrelated insights permeate student learning across law programs.

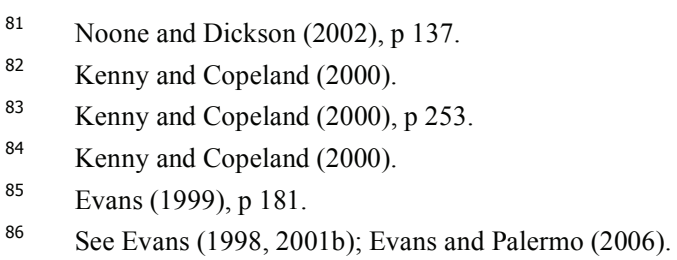




\section{Clinic and Pro Bono}

The past decade has seen increasing Australian government interest in the development of pro bono legal services. A National Pro Bono Law Conference was held in mid-2000, organised at the initiative of then federal AttorneyGeneral Daryl Williams. ${ }^{87}$ In 2001, the National Pro Bono Task Force reported to the Attorney-General, emphasising the importance of clinical experiences in enabling all law students to enhance their appreciation of ethical standards and professional responsibility. ${ }^{88}$ The 2001 federal budget allocated funds for the establishment of a National Pro Bono Resource Centre, which was established in 2002. ${ }^{89}$ Subsequent national conferences have been held in 2003 and 2006. ${ }^{90}$ The work of the centre continues to include a strong focus on promoting pro bono and voluntary service opportunities to law students.

The development of more formalised pro bono contributions has raised issues of the appropriate links between clinical programs and pro bono. Clinics are an obvious link between the academy and the practising profession, and can consolidate their place within law schools through the development of effective professional alliances. McCrimmon correctly identifies that, while clinic and pro bono are similar, they are not synonymous and may be concerned with different objectives..$^{91}$ Nonetheless, clinical pedagogy - with its emphasis on critique and reflection - is considered by McCrimmon as capable of instilling in students 'a desire to promote justice, fairness and morality for the poor, disadvantaged and marginalised members of society'. ${ }^{22}$ In 2004, the National Pro Bono Resource Centre published an Information Paper, Pro Bono and Clinical Legal Education Programs in Australian Law Schools, which identified a diverse range of clinical courses and not-for-academic-credit pro bono activities in Australian law schools. The paper noted that clinical and pro bono programs are likely to have different goals, but described both as 'vital components of a comprehensive social justice education at law school'. ${ }^{93}$

The information paper emphasised that both clinical education and pro bono activities are on the rise in Australian law schools. Amongst a general diversification of clinic sites and the emergence of public-interest law clinics, pro bono agencies like the Public Interest Law Clearing Houses in Victoria, New South Wales and Queensland now host clinics and also benefit from the volunteer contributions of students. The information paper illustrates the strong historical links between clinical teachers and Australian community legal centres and the strong community service focus of Australian clinics.

In a number of countries, clinical programs initially developed out of volunteer programs, for instance. Springvale Legal Service operated with very

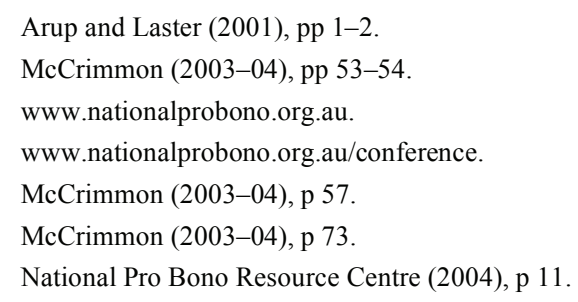


substantial volunteer input from Monash law students for two years before it became Australia's first clinical legal education site. As in a number of other US law schools, Yale Law School students first became involved in organised volunteer programs in the late 1920s; however, it took more than 40 years for this volunteer commitment to develop into a for-credit clinical program..$^{94}$ The clinic at the University of Natal, Durban started on a voluntary basis for both students and academics, but it was six years before students were granted credit for their work. ${ }^{95}$

This history suggests that clinical programs may develop from current law school pro bono initiatives. A volunteer program may be a stepping stone to the establishment of a clinical program with a heightened focus on community service. Nonetheless, McCrimmon notes that funding constraints mean that alternative strategies to promote a public service ethos amongst law students require consideration. ${ }^{96}$

It is clear that there is scope to strengthen the links between clinic courses and pro bono legal service providers, and attention should be paid to mapping the various possibilities. At the same time, it is important to consider the question raised by Cath Sylvester as to whether a greater emphasis on pro bono initiatives will have an adverse impact on the small clinical movement in England. ${ }^{97}$ She notes that the existing English clinics 'have always had, at their forefront, educational priorities. The increase in pro bono initiatives and greater involvement of students in legal practical work may compromise this. ${ }^{98}$

\section{Clinical Education in Other Disciplines}

Clinical education has an extensive tradition in other disciplines, particularly the health sciences, education and social work. McAllister and colleagues refer to 14 groups of health professionals as benefiting from sound clinical education practices in their field, ${ }^{99}$ while Brayne and colleagues refer to the use of clinical methods in the training of students including engineers, linguists, teachers and computer programmers. ${ }^{100}$ Legal education appears to be the 'odd one out' as a profession that has not emphasised clinical training. ${ }^{101}$ It appears that clinical

\footnotetext{
$94 \quad$ Holland (1999), pp 510-11.

95 David McQuoid-Mason, personal interview at Krakow, 25 July 2004.

$96 \quad$ McCrimmon (2001), p 94.

97 Sylvester (2003).

98 Sylvester (2003), p 36.

99 McAllister et al (2001), p ix. Reference is made to doctors, nurses, physiotherapists, speech therapists, occupational therapists, social workers, psychologists, dietitians, diversional therapists, podiatrists, dentists, medical radiation technologists, orthoptists, optometrists and rehabilitation counsellors.

100 Brayne et al (1998), p 3.

101 The Carnegie Report observes: 'Compared with the centrality of supervised practice, with mentoring and feedback, in the education of physicians and nurses or the importance of supervised practice in the preparation of teachers or social workers, the relative marginality of clinical training in law schools is striking.' Sullivan et al (2007), p 24.
} 
legal educators can benefit from actively engaging with like-minded colleagues from other disciplines, both in terms of refining supervision practices and better understanding other service delivery models.

While there are valuable insights that can be gained from the theory and practice of clinical educators in other disciplines, it is important to note that there are distinctive aspects of clinical method in legal education. While most disciplines involve solo-student or at most double-student placements, legal clinics tend to involve six or eight students per session. Other disciplines utilising clinical methods tend to be more vocation-focused than law. This may account for clinical learning being less prominent in legal education, as indicated by its elective status. The need for law graduates to complete further education prior to admission to practice is another distinguishing feature, which is discussed in further detail below. The placements in other disciplines also tend to be longer and more intense. In other disciplines, supervisory processes include a strong focus on observation of the student interacting, as a professional, with the client. Live client legal clinics tend not to permit direct supervisor observation of all aspects of a student's work. In summary, other disciplines tend to be using clinical teaching methods in what legal clinicians would describe as an externship model.

Tomain and Solimine argue that the medical school model of clinical education does not work in the US law school graduate degree context: 'Medical school may last ten years or more; we cannot successfully teach skills beyond the three Rs - legal reading, writing, and research — in only three years.' ${ }^{102}$ Cramton refers to both medical and legal education as failing to sufficiently foster self-learning and intellectual curiosity, 'despite their critical importance in the maintenance of professional competence over a long period of practice in a rapidly changing society' ${ }^{103}$ Cramton suggests that legal education 'errs in giving too little exposure to clinical experience', and asks whether medical education errs 'at the other extreme by devoting too much time to routine patient care narrowly oriented to body organs rather than the whole being of the patient'. ${ }^{104}$

In their book, Facilitating Learning in Clinical Settings, McAllister and colleagues emphasise professional socialisation and skills development as goals of clinical education with the goal being interdependent learning. ${ }^{105}$ They trace the developing nature of the role of the clinical supervisor, from the clinical instructor of the 1960s who, "with almost "amateurish enthusiasm" drilled students to reproduce traditional procedures' to the clinical teacher of the $1980 \mathrm{~s}$ with a stronger emphasis on individual student development to the current role of the clinical educator, 'developing in students a breadth of personal, interpersonal and management skills'. ${ }^{106}$

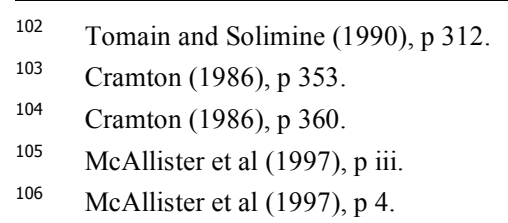


McAllister and colleagues provide a list of goals of clinical education for the health science professions which deal with understanding the context in which professional work takes place, technical competence in client-related work and the development of an ethical framework. ${ }^{107}$ They are clear that service must take precedence over educational goals. With very little discussion, they state: 'Since client care is always the priority, clinical educators may, on occasion, have to place student learning as second priority to ensure that the optimal client care is provided.' ${ }^{108}$

\section{Student Supervision}

It is interesting to contrast the service focus of clinical education in other disciplines with the focus on close student supervision which is considered a hallmark of clinical legal education. The practice-based context of clinical legal education has the potential to offer a very rich learning environment. However, the benefits of such an environment may be lost or diluted without close supervision or if the supervision is not focused on facilitating student learning as well as on controlling casework. Developing an environment in which students feel both suitably supported and challenged is a key aspect of the work of the clinic supervisor. It is also what makes clinical teaching more expensive than lecture and seminar-based programs.

Australian clinical law teachers have tended to receive limited training in relation to supervision. They would likely benefit from an enhanced appreciation of the supervision practices used in the health sciences and other disciplines. There is a need to articulate and test the assumptions that appear to be made regarding the effectiveness of those supervision practices used in private legal practice and in community legal centres.

Clinical models involving provision of advice to real clients require students to assume responsibility for their actions in a much more direct way than in other forms of legal education. In such programs, students are compelled to recognise that their actions will influence the well-being of others, namely their clients: "It necessarily follows from the touchstone of "realism" that a student in role must bear responsibility for the resolution of the problem.' ${ }^{109}$

Clinical teaching invites the student into relatively 'uncharted waters', but does so with a safety net of support structures involving preliminary preparation and close supervision. The student is provided with the opportunity to take greater control over their future learning as they test for themselves the best ways to approach issues and problems. This relates to the norms of current legal practice but also, and most importantly, extends to assisting students to develop a framework for how they will approach the need for ongoing learning and development throughout their professional life. Amsterdam refers to traditional legal education as having 'failed to develop in students ways of thinking within and about the role of lawyers - methods of critical analysis, planning and

\footnotetext{
107 McAllister et al (1997), p 11.

108 McAllister et al (1997), p 57.

$109 \quad$ Boon et al (1987), p 67.
} 
decision making which are not themselves practical skills but rather the conceptual foundations of practical skills and for much else'. ${ }^{110}$

Effective supervision can also introduce students to the range of uncertainties which legal professionals must address in their work. These include uncertainty as to what has taken place and why, whether a client's account is likely to be accepted by relevant third parties, which legal doctrines are relevant to the issue facing the client and how those doctrines are likely to apply. Assisting students to develop the ability to deal with unstructured situations is invariably a key objective of live-client clinical programs.

The presence of close supervision enables students to take on work involving greater responsibility because of the continuing availability of support. Such supervision may be more difficult to provide in clinics which prioritise the provision of community service as well as student learning. Rice refers to this difficulty as follows: 'A directive approach, giving the student instructions on the next necessary step to take, may at times be a legacy of a clinic that serves, as is often the case, the dual purpose of community service and student education. A clinic should be established so as not to be prey to the demands of casework that can swamp and compromise clinical supervision.' ${ }^{111}$

Supervision issues have been an area of disagreement in the US clinical field between the advocates of different clinical models, particularly between those endorsing externships and those supportive of in-house clinics. Divergent views have been taken of the learning benefits from having students supervised by a practitioner academic rather than an external person who, while often having lengthy practice experience, must juggle other responsibilities and may have little experience in working supportively with students. ${ }^{112}$

Givelber and colleagues have disputed the focus on the significance of academic supervision. On the basis of their analysis of the 'co-op' externships program at Northeastern University, they suggest that 'the nature and intensity of the work are at least as important as any aspect of supervision in explaining what distinguishes a good learning environment. This finding challenges one of the bedrock assumptions of clinical methodology - the centrality of an intensive, education-focused supervisory relationship.' ${ }^{113}$ Further, they 'insist that there is absolutely no empirical support for the notion that learning can occur only' under circumstances where 'a professional educator is on the

$110 \quad$ Amsterdam (1984).

111 Boone et al (1987), p 66.

112 This tension is usefully highlighted in the 1991 AALS Committee Report referred to earlier in this chapter which noted: 'There is a marked difference in how schools rated the level of extern supervision. Schools without in-house clinics tended to rate their level of extern supervision as high, while schools that had in-house clinics most frequently rated extern supervision as low.' Various explanations are given for these variations, the most interesting being that they 'represent self-serving statements on both sides, with schools having in-house clinics minimizing the supervision offered to externs, while schools without in-house clinics seek to defend externships as a viable alternative'. Dinerstein (1991). p 550.

113 Givelber et al (1995), p 3. 
scene'. ${ }^{114}$ Givelber and colleagues found that 'both the characteristics of the job and (emphasis in original) the presence of supervision play important roles in students' evaluations of their work experiences'. ${ }^{115}$

It is also worth noting that placing academic supervision as a central pillar of clinical legal education has the effect of limiting the number of students who can access clinical learning opportunities. In 1992, Stephen Maher referred to the focus of US clinics moving from service to education as they became more reliant on law school resources. Maher criticised the existing 'clinical orthodoxy', which emphasised the importance of 'close faculty supervision of case work' as the 'touchstone of clinical education' ${ }^{116} \mathrm{He}$ argued that clinical teachers might have 'secured their beachhead within the law school by assuming the burden of case work and the obligation of orthodoxy', but had been left unable to respond to the biggest challenge in clinical legal education: that of making clinical experiences available to more students. ${ }^{117}$

\section{Providing Initial Advice: Student or Supervisor?}

In a 1984 paper, Robyn Lansdowne and Neil Rees, then the supervising lawyers in the University of New South Wales clinical program, noted that they faced the 'difficult task of leading students to believe that they must accept responsibility for the conduct of a particular case whilst at the same time ensuring that our clients are not disadvantaged in any way by student involvement. In part, we have to create an illusion of responsibility. ${ }^{118}$ This has been described as akin to placing each student on a rope that is 'gradually let out if a student is performing well. If a student fails to perform adequately we are forced to draw in the rope and explore every minor detail of a case with the student. ${ }^{119}$

How this illusion of responsibility is maintained remains one of the few significant differences amongst Australian clinical programs. While all Australian real-client clinical programs provide students with the opportunity to take instructions from clients without their supervisor being present, different approaches are taken to the provision of advice to the client once the student and supervisor have determined what advice is to be provided to the client. When a client is being interviewed for the first time at either the University of New South Wales or Newcastle clinic, the student will not advise the client alone. They do so with their supervisor. Clinical programs outside New South Wales use the approach pioneered at Monash whereby the student returns to the client and advises them unaccompanied by a supervisor.

All programs share a similar approach to preparing students for their involvement in interviewing clients. In the first weeks of their placement,

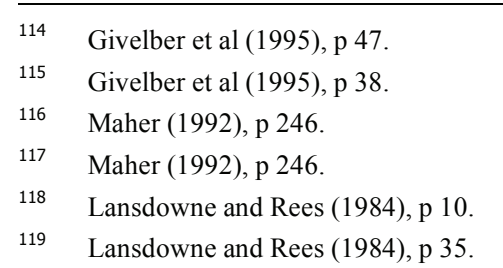


students observe interviews conducted by their supervisor and former students, and are then involved in intensive seminars using simulations to develop their interviewing and advising skills. Such a model allows very competent students to perform to their capacity as opposed to some artificially lower level of responsibility. ${ }^{120}$

This issue is of particular importance because supervisors do not generally have the opportunity to observe students as they conduct client interviews. Several leading Australian clinical teachers advised that they had never observed students conducting interviews with real clients as opposed to simulated interviews. ${ }^{121}$ Some US programs video-record students conducting interviews, enabling supervisors to provide feedback to students. Of course, video-recording raises confidentiality issues for clients and is likely to be disconcerting for at least some students.

The University of New South Wales model is relatively resource intensive, as several practitioners are required to provide coverage of all interviews conducted. The University of New South Wales has been able to make substantial use of lawyers seconded from law firms and government agencies to provide more time for the practitioner-academics to focus on matters other than the provision of advice in each case. Former Kingsford Legal Centre Director Simon Rice views the University of New South Wales approach as appropriate both from a client service perspective and educationally. While not wanting 'to take away the unique student-client dynamic', he saw 'a very useful role for a solicitor to lead by example and teach' as well as to safeguard the quality of advice provided 'when there's that degree of seriousness'. ${ }^{122}$ A further value of the Kingsford model is that the supervisor provides some continuity where the matter continues beyond one semester and so the client must deal with a different student. It also provides the client with the confidence that comes from maintaining a connection with the supervising lawyer.

Leading English clinical scholar Hugh Brayne candidly outlines how he changed his approach to sitting in on student interviews with clients. ${ }^{123}$ For his first four years as a clinical supervisor, Brayne 'sat in on every student interview', thinking 'that I had a professional responsibility to do so'. Subsequently, following discussions with clinic teachers in the United States, he almost never sat in on student-client interviews. He became concerned to avoid usurping the student's relationship with the client. Brayne considered that his previous approach had come from 'a failure to separate the two goals of legal service and student learning'. ${ }^{124}$

While Brayne's argument in favour of allowing students to conduct their interviews and provide advice without their supervisor present is compelling, the best model no doubt depends on the individuals involved, both the

120 Adrian Evans, personal interview at Sydney, 10 December 2002. 
supervisor and the student. Particularly able students will benefit from the opportunity to assume greater control over the advice process. The extent of preparation of students will also be significant. Perhaps the starting point should be that students should observe interviews conducted by both practitioners and experienced students. Students may also find it useful to conduct joint interviews together with a fellow student. For such a model to work effectively, students need to be taught how to effectively provide feedback to their peers.

Supervision arrangements that devolve substantial responsibility to students need to be supported by structures that effectively prepare students for this significant duty. Such preparation can occur early in a clinical placement, and can also be scaffolded by simulated activities in other law studies completed prior to the start of their clinic-based experience.

\section{The Move to Graduate Clinical Programs}

Requirements for law graduates to complete further professional training prior to admission to practice have influenced the manner in which Australian clinical legal education has developed over the past decade. In 1996, Rice referred to the blurring of the line between clinical legal education and practical legal training. ${ }^{25}$ While some states provide for law graduates to complete either articles of clerkship or a Practical Legal Training (PLT) Program in order to gain professional admission, other states - notably New South Wales - have removed the articles option and require any law graduate to complete a PLT program before admission to practice. ${ }^{26}$ The expansion in New South Wales of the number of PLT providers has been followed by similar moves in both Victoria and Queensland. ${ }^{127}$ In states where articles of clerkship remain an alternative post-degree route to admission, major national law firms now have their 'graduate clerks' complete a PLT program rather than articles. ${ }^{128}$

The University of Newcastle Law School was the first in Australia to offer a program combining completion of a law degree with the post-degree requirements for admission to legal practice. To achieve this, Newcastle Law School moved clinical teaching to the centre of the curriculum, aiming to take the lessons from live-client clinic work into the classroom. Simulations, more a feature of the PLT landscape at that time than of undergraduate law teaching, were also used more comprehensively than elsewhere. The Newcastle Legal Centre was the vehicle developed to operationalise this vision of a 'clinical law school'. ${ }^{129}$ Similar arrangements to fold PLT requirements into the law degree operate at other law schools, but without the same strong focus on clinic-based real-client work.

The continuing development and increased prominence of PLT programs may place pressure on undergraduate clinical programs to focus more directly

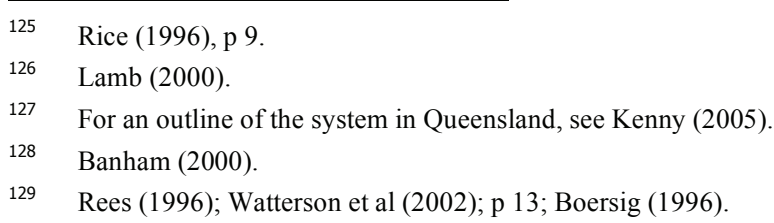


on skills teaching. Clinical teachers may also receive additional requests to contribute their practice expertise to non-clinic courses. Of course, such involvement in other courses may well benefit a clinical program in terms of enabling the effective preparation of students for subsequent clinical experiences. ${ }^{130}$

This focus on legal skills teaching provides a challenge for clinic teachers in PLT programs to encourage a broad perspective and avoid a transactional focus. Newcastle Legal Centre founder John Boersig has emphasised that planners must keep in mind the need to ensure courses do more than simply teach students simple mechanical tasks like the completing of forms. Such programs need to emphasise the teaching of generic skills 'essential to a broad range of legal activities', ${ }^{131}$ along with promoting reflection and critical analysis. Clinical teachers have skills and expertise that can assist with promoting a broad client-centred approach to the study of law.

\section{Conclusion}

This article has considered some of the issues that will continue to influence the directions in which clinical legal education programs will continue to develop. It has emphasised the value of recognising the various purposes - for students, law schools and legal academics - that can be advanced through the use of clinical teaching methods. Groups with interests in legal education, including the practising legal profession, have emphasised the benefits that can be gained by students through clinic-based learning about the law. Other groups have highlighted the importance to communities of the legal services provided by clinical programs. Clinical education is also recognised as important in the development of ethical frameworks and a focus on the interests and concerns of clients.

While the establishment of new clinical legal education programs is important, closer attention needs to be paid to sustaining programs over the long-term. The sustainability of a particular clinical experience within a broader clinical program requires the setting of realistic objectives (recognising the variables that impact on this process) and then the careful selection of a model that will facilitate meeting those objectives. Different models should then be integrated, where appropriate, and sequenced to enable clinical experiences to build on the understandings that students have already developed. The complexity of working with real clients should be seen as the logical progression of the consolidation and extension of understandings that have already been developed.

Chapter 5 of the Best Practices Report provides a comprehensive set of best practice standards that can be used to guide the development of experiential learning opportunities. ${ }^{132}$ It encourages clinic teachers to focus on promoting

\footnotetext{
130 For an effective outline of the links between different models of clinical legal education, see Maranville (2000-01).

131 Boersig (1996), p 466.

132 Stuckey et al (2007) Ch.5.
} 
those learning opportunities that are particularly well suited to clinic contexts ethics and values, skills development and legal problem-solving. The framework also emphasises the importance of course design, particularly the articulation of clear objectives and assessment criteria along with the effective provision of feedback.

Clinical teaching can also benefit from deeper understanding of the workintegrated teaching practices used in other disciplines, where clinic-based learning is more central. It also has the potential to promote opportunities for multi-disciplinary learning opportunities. This would be a significant step forward for a discipline that the Carnegie Report describes as striking for its lack of focus on clinical experiences as part of professional preparation. ${ }^{133}$

\section{References}

\section{Secondary Sources}

Anthony Amsterdam (1984) 'Clinical Legal Education — a 21st Century Perspective' 34 Journal of Legal Education 612.

Christopher Arup and Kathy Laster (2001) 'Introduction' 19 Law in Context 1.

Auditor-General Victoria (2004) Beyond the Triple Bottom Line: Measuring and Reporting on Sustainability, Victorian Government.

C Banham (2000) ‘Big Firms Take Student Training In-House' 5 May, Justinian.

David Barnhizer, (1979) 'The Clinical Method of Legal Instruction: Its Theory and Implementation' 30 Journal of Legal Education 67.

Frank Bloch and Iqbal Ishar (1990) 'Legal Aid, Public Service and Clinical Legal Education: Future Directions From India and the United States' 12 Michigan Journal of International Law 92.

John Boersig (1996) 'Clinical Legal Education: The Newcastle University Model', paper presented at the Australasian Professional Legal Education Council International Conference, Skills Development for Tomorrow's Lawyers: Needs and Strategies, Sydney, September, published in Conference Papers Vol 1.

Andrew Boon, Michael Jeeves and Julie MacFarlane (1987) 'Clinical Anatomy: Towards a Working Definition of Clinical Legal Education' 21 Law Teacher 61.

Andrew Boon (2001) Paper presented to University of Westminster Making Good Lawyers: Challenges to Vocational Legal Education conference, 26 September.

Hugh Brayne (1996) 'Law Students as Practitioners: Developing an Undergraduate Clinical Programme at Northumbria University', in J Webb and C Maughan (eds), Teaching Lawyers' Skills, Butterworths.

Hugh Brayne, Nigel Duncan and Richard Grimes (1998) Clinical Legal Education: Active Learning in Your Law School, Blackstone.

Robert Condlin (1983) 'Clinical Education in the Seventies: an Appraisal of the Decade' 33 Journal of Legal Education 604.

Roger Cramton (1986) 'Professional Education in Medicine and Law: Structural Differences, Common Failings, Possible Opportunities’ 34 Cleveland State Law Review 349.

133 Sullivan et al (2007) p 24. 
Liz Curran (2004) 'Innovations in an Australian Clinical Legal Education Program: Students Making a Difference in Generating Positive Change' 4 International Journal of Clinical Legal Education 162.

Judith Dickson and Mary Anne Noone (1996) 'The Challenge of Teaching Professional Ethics', paper presented at the Australasian Professional Legal Education Council International Conference, Skills Development for Tomorrow's Lawyers: Needs and Strategies, Sydney, New South Wales, September, Conference Papers, Vol 2.

Robert Dinerstein (1991) 'Report of the Committee on the Future of the In-House Clinic' 41 Journal of Legal Education 508.

Michael Dowdle (2000-01) 'Preserving Indigenous Paradigms in an Age of Globalization: Pragmatic Strategies for the Development of Clinical Legal Aid in China' 24 Fordham International Law Journal S56.

Dexter Dunphy, Andrew Griffiths and Suzanne Benn (2003) Organizational Change for Corporate Sustainability, Routledge.

Adrian Evans (1996) 'Specialised Clinical Legal Education Begins in Australia' 21(2) Alternative Law Journal 79.

Adrian Evans (1998) 'The Values Priority in Quality Legal Education: Developing a Values/Skills Link Through Clinical Experience’ 32(3) Law Teacher 274.

Adrian Evans (1999) 'Client Group Activism and Student Moral Development in Clinical Legal Education' 10 Legal Education Review 179.

Adrian Evans (2001a) 'Efficacy Beyond Reasonable Doubt?' 19 Law in Context 89.

Adrian Evans (2001b) 'Lawyers' Perspectives of Their Values: An Empirical Assessment of Monash University Graduates in Law, 1980-1998' 12 Legal Education Review 209.

Adrian Evans and Josephine Palermo (2006) 'Preparing Australia's Future Lawyers: An Exposition of Changing Values Over Time in the Context of Teaching about Ethical Dilemmas' 11(1) Deakin Law Review 103.

Mark Galanter and Thomas Palay (1991) The Tournament of Lawyers: The Transformation of the Big Law Firm, University of Chicago Press.

Shelley Gavigan (1997) 'Twenty-five Years of Dynamic Tension: The Parkdale Community Legal Services Experience' 35(3) Osgoode Hall Law Journal 443.

Jeff Giddings (1992) 'Casework, Bloody Casework' 17(6) Alternative Law Journal 261.

Jeff Giddings (1999) 'A Circle Game: Issues in Australian Clinical Legal Education' 10(1) Legal Education Review 33.

Jeff Giddings (2003) 'Clinical Legal Education in Australia: A Historical Perspective' 3 International Journal of Clinical Legal Education 7.

Jeff Giddings (2005) 'Clinical Sustainability', Keynote address to the $3^{\text {rd }}$ International Journal of Clinical Legal Education Conference, Melbourne, 14 July.

Daniel Givelber, Brooke Baker, John McDevitt and Robyn Miliano (1995) 'Learning Through Work: An Empirical Study of Legal Internships' 45(1) Journal of Legal Education 1.

Andrew Goldsmith (2002) 'Why Should Law Matter? Towards a Clinical Model of Legal Education' 25(3) UNSW Law Journal 721.

Kerry Greenwood (1994) It Seemed Like a Good Idea at the Time: A History of Springvale Legal Service 1973-1993, Springvale Legal Service.

Richard Grimes (1995) 'Reflections on Clinical Legal Education’ Law Teacher 169.

Richard Grimes (1996) 'The Theory and Practice of Clinical Legal Education', in J Webb and C Maughan (eds), Teaching Lawyers' Skills, Butterworths. 
Laura Holland (1999) 'Invading the Ivory Tower: The History of Clinical Education at Yale Law School' 49(4) Journal of Legal Education 504.

Richard Johnstone and Sumitra Vignaendra (2003), Learning Outcomes and Curriculum Development in Law, Australian University Teaching Committee.

C Kenny (2005) ‘Graduate Legal Training — The New Regime’ July Proctor 12.

Mary Anne Kenny and Anna Copeland (2000) 'Clinical Legal Education and Refugee Cases: Teaching Law Students About Human Rights’ 25(5) Alternative Law Journal 252.

Sue Kenny (1999) Developing Communities for the Future: Community Development in Australia, Nelson.

Kingsford Legal Centre (2007) Clinical Legal Education Guide, Kingsford Legal Centre.

Ainslie Lamb (2000) 'Preparation for Practice: Recent Developments in Practical Legal Training in Australia', paper presented at the Commonwealth Legal Education Association Conference, Adelaide, April.

Robyn Lansdowne and Neil Rees (1984) 'Kingsford Legal Centre: A Clinical Experience', paper presented to the conference of the Australian Law Teachers Association.

Paul Maharg (2007) Transforming Legal Education: Learning and Teaching the Law in the Early Twenty-first Century, Ashgate.

Stephen Maher (1992) 'No Easy Walk to Freedom' 1 District of Columbia Law Review 243.

Deborah Maranville (2000-01) 'Passion, Context, and Lawyering Skills: Choosing Among Simulated and Real Client Experiences' 7 Clinical Law Review 123.

Lindy McAllister, Michelle Lincoln, Sharynne McLeod and Diana Maloney (2001), Facilitating Learning in Clinical Settings, Nelson Thornes.

Les McCrimmon (2001) 'Law School Clinics Plus' 19 Law in Context 92.

Les McCrimmon (2003-04) 'Mandating a Culture of Service: Pro Bono in the Law School Curriculum' 14(1) Legal Education Review 53.

David McQuoid-Mason (1982) An Outline of Legal Aid in South Africa, Butterworths.

Bruce Moore (ed) (1999) The Australian Oxford Dictionary, Oxford University Press.

Mary Anne Noone and Judith Dickson (2002) 'Teaching Towards a New Professionalism: Challenging Law Students to Become Ethical Lawyers’ 4(2) Legal Ethics 127.

National Pro Bono Resource Centre (2004) Information Paper - Pro Bono and Clinical Legal Education Programs in Australian Law Schools, National Pro Bono Resource Centre.

David Pearce, Enid Campbell and Donald Harding (1987) Australian Law Schools: A Discipline Assessment for the Commonwealth Tertiary Education Commission: A Summary and Volume 1, AGPS.

Allen Redlich (1970-71) 'Perceptions of a Clinical Program' 44 Southern California Law Review 574.

Neil Rees (1996) 'A Clinical Law School' 6 University of Newcastle Centre for Advancement of Learning and Teaching Newsletter 2.

Simon Rice (1996) A Guide to Implementing Clinical Teaching Method in the Law School Curriculum, Centre for Legal Education (Sydney).

Ysaiah Ross (2001) Ethics in Law: Lawyers' Professional Responsibility and Accountability in Australia, 3rd ed., Butterworths.

Philip Schrag and Michael Meltsner (1998) Reflections on Clinical Legal Education, Northeastern University Press.

Roy Stuckey et al (2007) Best Practices for Legal Education: A Vision and a Road Map, Clinical Legal Education Association. 
Irene Styles and Archie Zariski (2001) 'Law Clinics and the Promotion of Public Interest Lawyering' 19 Law in Context 65.

William Sullivan, Anne Colby, Judith Wegner, Lloyd Bond and Lee Shulman (2007) Educating Lawyers: Preparation for the Profession of Law, Jossey-Bass.

Cath Sylvester (2003) 'Bridging the Gap? The Effect of Pro Bono Initiatives on Clinical Legal Education in the UK' 3(1) International Journal of Clinical Legal Education 29.

Joseph Tomain and Michael Solimine (1990) 'Skills Skepticism in the Postclinic World' 40 Journal of Legal Education 307.

Ray Watterson, Robert Cavanagh and John Boersig (2002) 'Law School Based Public Interest Advocacy' 2 International Journal of Clinical Legal Education 1.

Lucy White (1997) 'The Transformative Potential of Clinical Legal Education' 35(3) Osgoode Hall Law Journal 603.

Rick Wilson (2002) 'Three Law School Clinics in Chile, 1970-2000: Innovation, Resistance and Conformity in the Global South' 8 Clinical Law Review 515.

David Yencken (2001) Where Are We Going? Comprehensive Social, Cultural, Environmental and Economic Reporting, The Australian Collaboration (Melbourne).

\section{Cases}

Eastman v The Queen [2000] HCA 29.

Williams $v$ The Minister Aboriginal Land Rights Act 1983 and The State of New South Wales [2000] NSWCA 255. 